\title{
Biosynthesis of Nano Zinc and Using of Some Nanoparticles in Reducing of Cercospora Leaf Spot Disease of Sugar Beet in The Field
}

\author{
Gamal A. Farahat \\ Agricultural Research Center, Plant Pathology Research Institute, Sakha Research \\ Station, Kafr El-Sheikh 33717, Egypt.
}

\begin{abstract}
B IOSYNTHESIS of Zn nanoparticles(NPs) from 32 various plant samples were tested and subjected to 11 samples of ZnONPs from plant aqueous extracts, wherever, $\mathrm{ZnNo}_{3}(1 \mathrm{mmole})$ was used as precursor to synthesizing of ZnONPs. The UV-Vis spectral analysis of Morus nigra and Grevillea robusta plant leaves mix extracts (reaction mixture) were confirmed and showed performance of Zn NPs and exhibited as new sources for clean production and could be explored in various fields. During two tested seasons 2015/2016 and 2016/2017 and field conditions showed that, NPs of Ti followed by Zn caused to reducing of cercospora leaf spot (CLS) disease severity percentage of sugar beet plants and enhancement of TSS and sucrose contents, especially under high disease severity stress in season 2015/2016 compared to protected plants by eminent fungicide and control. NPs led to activation and recorded high enzymes activity values of enzymes of peroxidase up to $6 \mathrm{~min}$ and polyphenoloxidase up to 4 min estimation periods compared to control, so exhibited as mechanism in defense against CLS disease. Unseasonable weather conditions of temperature degrees, relative humidity percentage, wind velocity, pan evaporation and rain played an essential role in changement of CLS disease severity and susceptibility under field conditions during two tested seasons. The results recorded high percentages with first date of planting in September month in the first season of 2015/2016 with seven sugar beet genotypes than the second ones of October month and season of 2016/2017.
\end{abstract}

Keywords: Biosynthesis ZnNPs, Cercospora leaf spot disease, Peroxidase, Weather conditions

\section{Introduction}

Cercospora leaf spot (CLS) disease caused by the polycyclic pathogen $C$. beticola is economically important in many beet growing regions and most serious foliar disease of sugar beet (Beta vulgaris L.) worldwide (Secor and Rivera 2010; Bolton et al. 2013) and can cause a reduction in gross sugar yield up to $42 \%$. Losses of $30-48 \%$ in recoverable sucrose are common under uncontrolled moderate to heavy disease pressure and losses have been reported as high as 43\% (Shane and Teng 1992; Khan and Smith 2005). Biosynthesis of green nanoparticles using plant extracts is interesting in the field nanotechnology, which has economic and eco-friendly benefits over chemical and physiological methods (Aniruddha and Bhalchandra 2013; Suzan et al. 2014). Several reports demonstrated the synthesis of ZnONPs from natural source like plants by green chemistry approaches (Babu and Prabu 2011; Salem et al. 2015; Manokari et al. 2016). Moreover, Kumar and Yadav (2009) indicated that, plant mediated NPs synthesis was performed as it was costeffective, ecofriendly and safe for human.

In recent years, pathogenic fungi had grown increasingly resistant to commercially available antimicrobial agents. This prompted researchers to look for alternative means to combat microbial and fungal pathogens. Use of NPs in plant disease management is a novel approach that may prove very effective in the future with the progress of application aspects of nanotechnology. NPs may suppress the pathogen in a way comparable to chemical pesticides. Moreover, the NPs can be used as a carrier of some chemicals viz, pheromones, SAR inducing chemicals, polyamine synthesis inhibitors (Khan et al. 2014). $\mathrm{TiO}_{2} \mathrm{NPs}$ have become one of the most

Corresponding author e-mail: g farahat@yahoo.com DOI: 10.21608/JENVBS.2018.5213.1035

C2017 National Information and Documentation Center (NIDOC) 
important substances in nanotechnology which caused plant growth promoting to roots of oilseed rape and protected the plants against Alternaria brassicae infection and adhesive effects on bacteria (Bacillus amyloliquefaciens; Palmqvist et al. 2015). $\mathrm{TiO}_{2} \mathrm{NPs}$ is useful as protective encapsulating agents that increase adhesive force in the interspecies relation between bacteria and plants (Chowdhury et al. 2012; Webster et al. 2008). Ruffolo et al. (2010) and Song et al. (2014) found that $\mathrm{ZnTiO}_{3}$ and $\mathrm{Zn}$ hydroxide carbonate NPs showed higher growth inhibition efficiency of $A$. niger and fungal activity against cotton Verticillium, Rhizopus, Mucorales than ZnONPs, respectively. Abd-Elsalam (2013) and Mahendra et al. (2012) showed that application of NPs grower-friendly in agriculture need to be readily used for protecting crops and avoiding loss to plant pathogens diseases. Moreover, Singh et al. (2013) reported that, among 15 micronutrients nanoforms, $\mathrm{CuSO}_{4}$ and $\mathrm{Na}_{2} \mathrm{~B}_{4} \mathrm{O}_{7}$ were found most effective in controlling rust disease of field peas. Also, Abd-El-Hai et al. (2009) added that, Mg and Zn NPs suppressed the damping off and charcoal rot disease in sunflower. Additionally, Graham et al. (2016) showed that, ZnNPs (zinkicide) spraying led to reducing of grapefruit canker lesion development and incidence than bacteriocide cuprous and $\mathrm{Zn}$ oxide also effective against fungal disease i.e. grapefruit scab and melanose. Khan and Rizvi (2014) added that, NPs have found suppressive to fungi. $\mathrm{Zn}$ plays a vital role for various metabolic pathways in plant system and plant diseases concerned to its deficiency, and improved growth and yield (Panwar et al. 2012). ZnONPs significantly inhibited the growth of many fungi i.e. Botrytis cinerea and Penicillium expansum (He et al. 2010 and Krishnaraj et al. 2012), A. flavus (Jayaseelan et al. 2012), A. niger and $\mathrm{F}$. oxysporum had antifungal (fungicidal) effects due to induce intracellular the generation of reactive oxygen species (ROS), Lipovsky et al. (2011) and Patra et al. (2012), Helmenthosporium oryzae (Elamawi et al. 2016) and F. verticilliods (Farahat et al. 2017). Application of ZnNPs mediated cytotoxicity and increase of ROS which effective to control plant pathogens (Wani and Shah 2012), lipid peroxidation and reduced glutathione (Muthurman et al. 2014). Hamaza et al. (2013) added that, ZnNPs can be promising to control of late wilt disease in maize by increasing of PO enzyme with enhancement of yield.

As effect of weather conditions of development of CLS disease, Khan et al. (2008) reported that, wind was the major dispersal factor for C. beticola inoculum. Consequently, CLS was the most destructive in relatively warm and humid conditions worldwide (Kerr and Weiss 1990; Karaoglanidis et al. 2001) and responsible for significant reduction in root yield sucrose and sucrose, while increasing the concentration impurities and processing costs. Windels et al. (1998) showed that, infection by $C$. beticola depending on weather conditions after infection. Moreover, Khan et al. (2007) showed that, unseasonably low temperature was probably the main factor for low disease severity in average 15 and $16{ }^{\circ} \mathrm{C}$ compared to $22^{\circ} \mathrm{C}$. Jones and Windels (1991) pointed that, optimum temperature for spore germination is $24.4{ }^{\circ} \mathrm{C}$, when relative humidity is $100 \%$. Consequently, Wolf et al. (2001) and Wolf and Verreet (2005) showed that, meteorological variables were considered as potential reasons for variation in epidemic onset of $C$. beticola, temperature optimum at 20 $25^{\circ} \mathrm{C}$ (disease development between $20-30{ }^{\circ} \mathrm{C}$ ) and RH 75 - more $90 \%$ (free water) but strongly inhibition by temperature bellow $10^{\circ} \mathrm{C}$. Harveson (2013) reported that, epidemics of CLS depend on the presence of susceptible varieties, adequate inoculum and long periods of leaf wetness (RH above $90 \%$, longer than 11 hours) accompanied by warm temperature in the crop canopy.

This work was aimed to provide data for biosynthesis of $\mathrm{Zn}$ nanoparticles using plant extracts, effect of zinc $(\mathrm{Zn})$, magnesium $(\mathrm{Mg})$ and titanium (Ti) nanoparticles of cercospora leaf spot disease under field and their relation to peroxidase and polyphenoloxidase enzymes activity, as well as effect of environmental conditions of cercospora leaf spot disease development under field conditions.

\section{Materials and Methods}

The present work was carried out at the experimental farm and Lab. of Sakha Agric. Res. Station, ARC, Egypt during 2015/2016 and 2016/2017 growing seasons.

\section{1- Biosynthesis of Zn NPs \\ a-Plant materials and extracts preparation}

Different plants as shown in Table 1 were used to make aqueous extracts. Healthy plant materials were collected from Kafr El-Sheikh location. Plant specimens were identified by Horticulture Sakha Research Station. Fresh leaves, stems and fruits were collected and washed with running 
tap water, dried cut to small pieces and used to prepare the extracts as methods of Manokari et al. (2016). Five gm of chopped plant parts were boiled in $50 \mathrm{ml}$ of distilled water for $5 \mathrm{~min}$ to prepare broth solution which filtrated and used as reducing agent.
b-Biosynthesis and spectral analysis of Zn NPs

Zinc nitrate hexahydrate $\left[\mathrm{Zn}\left(\mathrm{No}_{3}\right)_{2} \cdot 6 \mathrm{H}_{2} \mathrm{o}\right.$, Delta, Egypt Chemistries] 1millemole (mM) solution was used as precursor to synthesize $\mathrm{ZnO}$ NPs using plant extracts. Color changes observed with one hour by heating the reaction mixture at 60

TABLE 1. List and reaction of tested plant extracts to $\mathrm{ZnNPs}$ biosynthesis

\begin{tabular}{|c|c|c|}
\hline Latin name & Used parts & Reaction \\
\hline Melia azedarach & new leaves & + \\
\hline M. azedarach & old leaves & ++ \\
\hline M. azedarach & new stem & + \\
\hline M. azedarach & fruits & + \\
\hline Duranta erecta & leaves & +++ \\
\hline Cassia gloca & leaves & - \\
\hline Ziziphus spina-christi & leaves & - \\
\hline Ipomea palmate & leaves & - \\
\hline Ipomea carnia & leaves & - \\
\hline Ocimum basilicum & leaves & - \\
\hline Ricinus commmunis & leaves & - \\
\hline Bogainvillea spectabillis & leaves & - \\
\hline Eucalyptus golobus & leaves & - \\
\hline Rubus fruticocus & leaves & - \\
\hline Conyza odorata & leaves & - \\
\hline Lonicera japonica & leaves & - \\
\hline Bohinia variegate & leaves & - \\
\hline Gauva psidium & leaves & - \\
\hline Morus nigra & leaves, T1 & +++ \\
\hline M.nigra & leaves, T2 & +++ \\
\hline M.nigra & leaves, T3 & + \\
\hline M. alba & leaves, T4 & +++ \\
\hline M.nigra & leaves, T5 & +++ \\
\hline Phragnites communist & leaves & - \\
\hline Myoporum serratum & leaves & - \\
\hline Thevetia nereifolia & leaves & - \\
\hline Grevillea robusta & leaves & ++ \\
\hline Impreta cylindrical & leaves & - \\
\hline Nerium oleander & leaves & - \\
\hline Pheonix dactylifera & leaves & - \\
\hline Lantara camara & leave & - \\
\hline L. camara & new stem & - \\
\hline
\end{tabular}

+: yellow ; ++: dark yellow ; +++: very dark yellow; -:no color 
${ }^{\mathrm{o}} \mathrm{C}$ for $15 \mathrm{~min}$ which turned to stable yellow color. The reduction of pure zinc ions and the synthesized ZnONPs were confirmed and characterized by using UV-visible spectrophotometer (Model Spectronic 21). The UV-Vis absorption spectra of Znic colloids from Morus nigra and Grevillea robusta plant extracts were confirmed by using wave length scan between 200 to $600 \mathrm{~nm}$. Reaction mixture showed strong peak at $296 \mathrm{~nm}$ (absorbance peak) which was specific for the zinc NPs (Manokari et al. 2016).

\section{c- Effect of boiling period of biosynthesis of $\mathrm{Zn}$ $N P S$}

Three boiling periods, i.e. 1,3 and $6 \mathrm{~min}$ were tested to preparing of extracts for $\mathrm{ZnO}$ NPs biosynthesis from two samples of $M$. nigra leaves i.e. T1, Sawalha location and T5, Sakha location. Extraction, synthesis procedure and spectral analysis of Zn NPs were performed as adopted by Manokari et al. (2016).

\section{2-Effect of nanoparticles of cercospora leaf spot disease}

\section{Nanoparticles preparation}

Zinc oxide $(\mathrm{ZnO})$, magnesium oxide $(\mathrm{MgO})$ and titanium dioxide $\left(\mathrm{TiO}_{2}\right)$ nanoparticles (NPS) were obtained from MKImpex Corp Mississauga, ON L5N 6X1, Canada. According to the manufacturing and observation on Transmission Electron Microscopy (TEM), the particles size distributions were ranged from $30 \mathrm{~nm}$ and nearly spherical to hexagonal shaped with $\mathrm{ZnO}$ NPs, $20 \mathrm{~nm}$ with $\mathrm{TiO}_{2}$ NPs and $30 \mathrm{~nm}$ with $\mathrm{MgO}$ NPs, as shown in Fig. 1 (Farahat et al. 2017). For experiment, solutions were prepared freshly by dispersing nanoparticles in de-ionized water through ultra-sonication $(300 \mathrm{~W}, 40 \mathrm{kHz})$ for 30 minutes. Different concentrations of nanoparticles of MgO NPs, ZnO NPs (25, 50 and 100 ppm) and $\mathrm{TiO}_{2}$ NPs (50,100 and $\left.200 \mathrm{ppm}\right)$ were used under field conditions.

The experiment was carried out in $6^{\text {th }}$ October during 2015/2016 and 2016/2017 growing seasons. Randomized complete blocks design with three replicates was used. Every treatment applied in 3 rows, each with $6 \mathrm{~m}$ long at $15-20 \mathrm{~cm}$ distance between hills. Application of treatments and fungicide of eminent (recommended dose, 1 $\mathrm{cm} / \mathrm{L}$ ) as protected control were done after 90 days from sowing with three sprays 15 days intervals. All cultural practices were done at proper time. Sucrose and total soluble solids (TSS) were determined in fresh roots using sacarometer and refrectometer according to AOAC (1990) and McGinnis (1982), respectively as well as, disease severity percentage (DS) was recorded as modified scale of Shane and Teng (1992) and/or Stewart (2011) after 180 days from sowing.

\section{3- Assay of peroxidase and polyphenoloxidase activities}

Oxidative enzymes activity of peroxidase (PO) and poly-phenoloxidase (PPO) were estimated and expressed as changes of absorbance (optical density, OD and/or mg protein /gm fresh weight) after 10 days from the third spray application by $\mathrm{TiO}_{2}$ NPs (200 ppm), ZnO NPs (100 ppm) and $\mathrm{MgO}$ NPs (100 ppm), compared with control treatment. Enzymes extraction and peroxidase were assayed as methods adopted by Anjum et al. (2012) and poly-phenoloxidase was assayed as methods of Matta and Dimond (1963) using spectrophotometer (Spectronic $21 \mathrm{D})$.

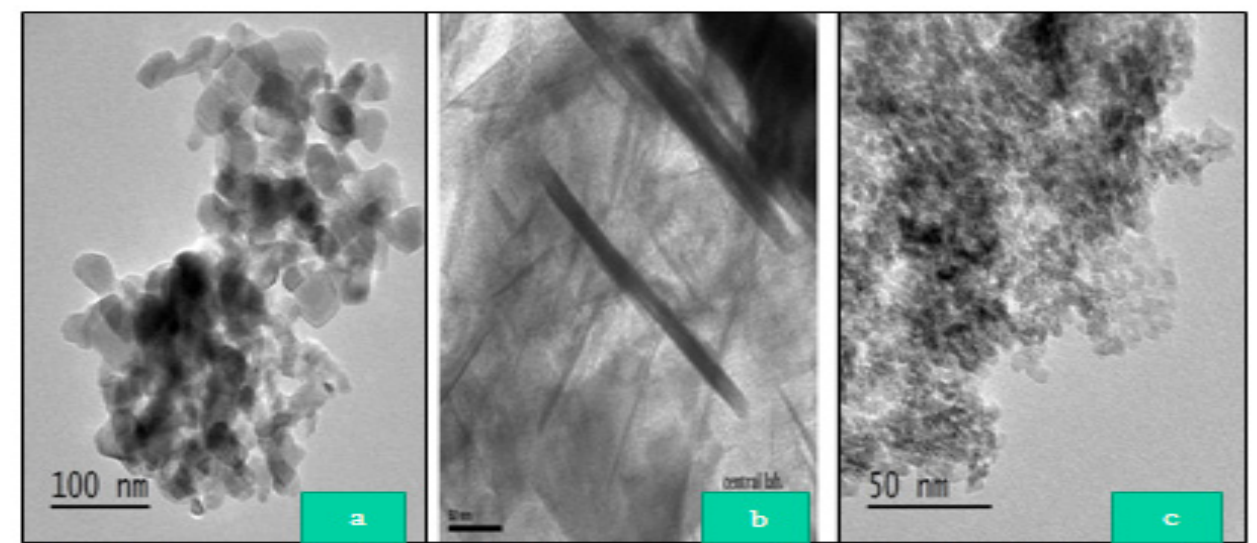

Fig. (1) : Transmission Electron Microscopy images of (a) ZnONP, (b) $M_{\underline{g}} O N \mathbb{P}$ and (c) $\mathrm{TiO}_{2} \mathrm{NP}$

Env. Biodiv. Soil Security Vol. 2 (2018) 


\section{4-Effect of environmental conditions of cercospora leaf spot disease in the field}

Accurately determine the effect of weather conditions like air temperature degrees ${ }^{\circ} \mathrm{C}$ (max. and min.), relative humidity (RH $\%$ at $7: 30$ and 13:30 O'clock ), pan evaporation (mm), rain $(\mathrm{mm})$ and wind velocity $(\mathrm{km} / 24 \mathrm{~h})$ of cercospora leaf spot disease development, meteorlogical data of these parameters through the seasons 2015/2016 and 2016/2017 during of November and December (disease development period for first date cultivation) and during January to March (disease development period for second date cultivation) were obtained from Rice Res. And Training Center at Sakha Agric. Res. Station, Egypt and will be mentioned later. Nine sugar beet genotypes, i.e. Alouda, Maimouna, Beta 3980 and 8115, Nefirtitis clg, Cigogne, Toucan, Carnute and Oscar poly were cultivated at two dates, the first at $10^{\text {th }}$ September and the second at $6^{\text {th }}$ October during 2015/2016 and 2016/2017 growing seasons. Randomized complete block design with three replicates was used. Every treatment applied in 3 rows, each with $6 \mathrm{~m}$ long at $15-20 \mathrm{~cm}$ distance between hills. All cultural practices were done at proper time. DS were determined as mentioned above.

\section{Statistical analysis}

Data were analyzed statistically by WASP1 (WASP-Wep Agri Stat Package) developed by Ashok Kumar Jangam and Pranjali Thali at ICAR Research Complex for Goa, India program, the analysis of variance and the means were further tested using the least significant difference test (LSD).

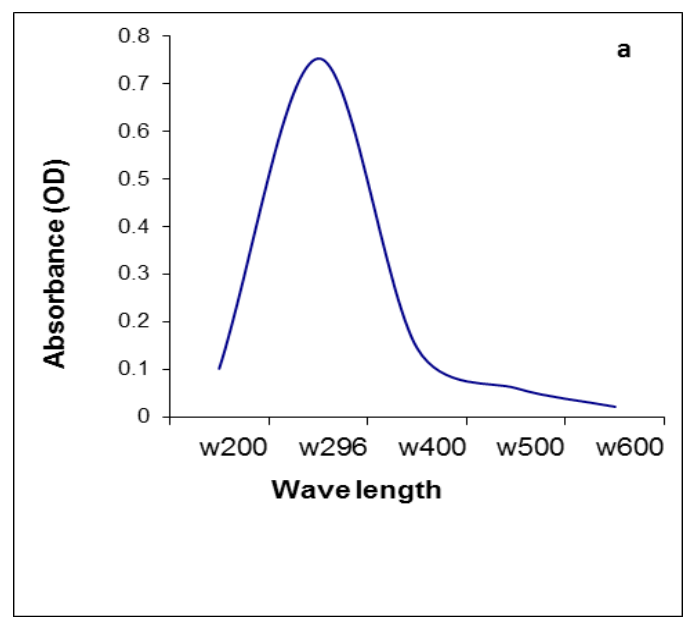

\section{Results and Discussion}

\section{1-Biosynthesis of Zn NPs:}

From 32 plant samples were tested according to Manokari et al. (2016) protocol using leaves and stems extracts listed in Table 1, Zinc oxide NPs was synthesized by only 11 samples after addition of aqueous zinc nitrate solution to extracts, color changes appeared within one hour by heating the reaction mixture at $60{ }^{\circ} \mathrm{C}$ for $15 \mathrm{~min}$ indicating the completing of the reaction. The intensity of colors steadily increased along the incubation period. In contrast, zinc nitrate solution without extracts and control (extract alone) showed negative reaction (no color changes). ZnNPs solutions exhibited dark yellow color, this due to reduction of aqueous extracts by Zn No3 (zinc ions) and formation of ZnNPs, Sangeetha et al. (2011). Four and five samples of both Melia and Morus, one sample of both Duranta and Grevillea, respectively, were designated to synthesis of ZnO NPS which yellow and / or dark yellow color was appeared, respectively. On the other hand, other tested samples showed no color change of reaction mixture and showed negative reaction. The UVVis spectral analysis of reaction mixtures of $M$. nigra and G.robusta confirmed the synthesis of $\mathrm{ZnO}$ NPs from leaves aqueous extracts by the using of wave length scan at $296 \mathrm{~nm}$ (absorbance peak) and showed strong absorbance (Fig. 2 a and b). Yellow and/or dark yellow color were appeared as shown in Fig. 3 in chemical reaction due to reduction of aqueous extracts by $\mathrm{Zn} \mathrm{No} 3$ (zinc ions) and formation of $\mathrm{ZnO}$ NPs from leaves aqueous extracts.

Fig. 2. UV-VIS spectra analysis of a) Morus nigra and b) Grevillea robusta mix extracts for Zn nanoparticles

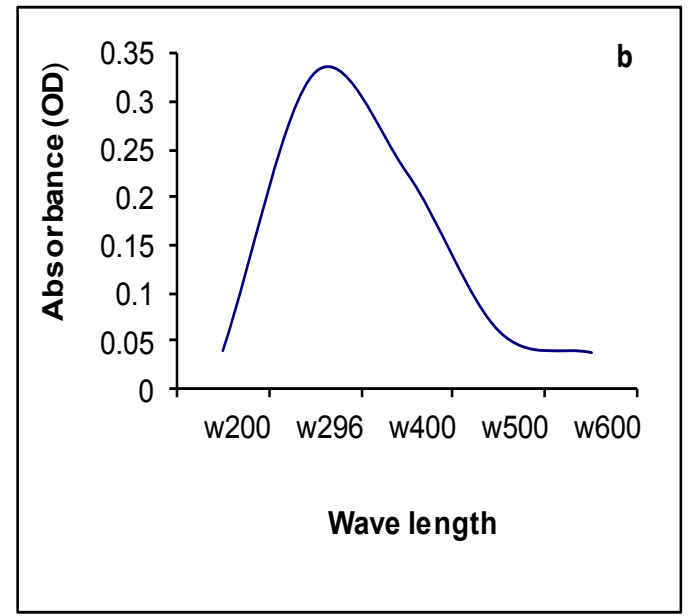




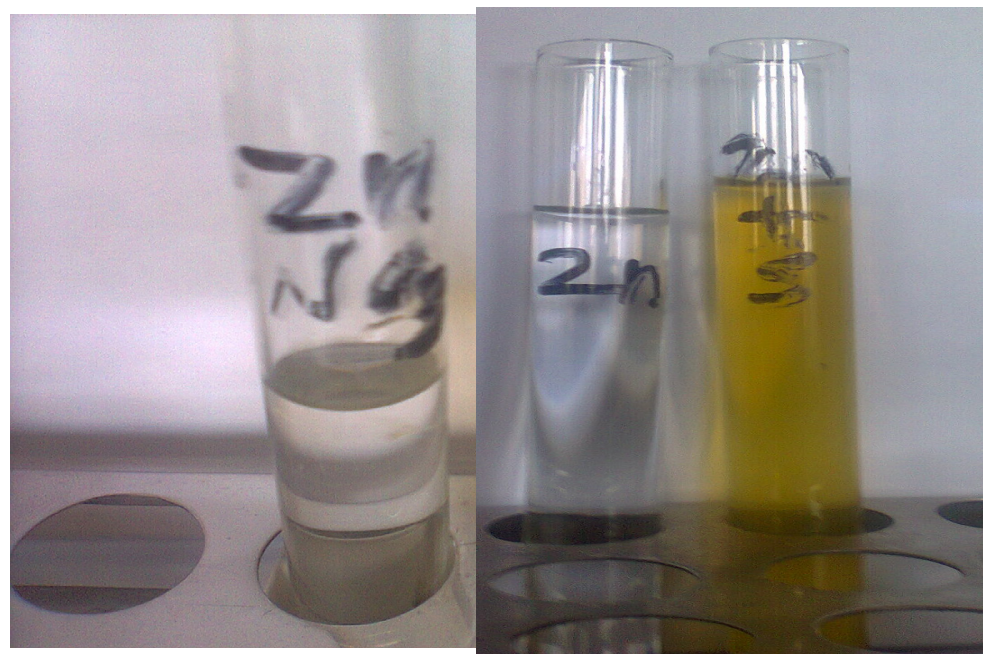

Fig. 3. Dark stable yellow with reaction mixture of Morus nigra, $\mathrm{T5}(\mathrm{Zn}+\mathrm{Ex})$ in the left, Grevillea robusta $(\mathrm{Zn}+\mathrm{S})$ in the right means confirmed of $\mathrm{Zn}$ NPS and $\mathrm{Zn}\left(1 \mathrm{mM}\right.$ of $\left.\mathrm{Zn} \mathrm{NO}_{3}\right)$ in the middle .

The bio reducing of aqueous zinc ions by M.nigra and G.robusta plants had been demonstrated and could be anew and good source for synthesis of ZnO NPs eco-friendly method.

\section{2- Effect of boiling period of biosynthesis of Zn NPS}

Data in Table 2 showed that, 6 min boiling of leaves spices of two tested samples of $M$. nigra i.e. $\mathrm{T} 1$ and $\mathrm{T} 5$ was suitable for prepare broth solution which used as aqueous extraction for biosynthesis of $\mathrm{ZnO}$ NPs. Addition of zinc nitrate solution to aqueous extracts of this samples lead to appear dark yellow color. The intensity of colors increased along the incubation period and recorded the highest absorbance (OD) at wave length of $296 \mathrm{~nm}$ i.e. 0.753 and 0.473 compared to other boiling periods of 1 and 3 min.T5 (Sakha location) sample confirmed the synthesis of $\mathrm{ZnO}$ NPs from aqueous extract of leaves with three boiling period more than T1 (sawalha location) wherever dark yellow and very dark yellow color were appeared compared to yellow and dark yellow with T1extraxts.

The present study concluded that, aqueous extracts of leaves of Melia, Duranta, Morus and Grevillea were designated to synthesis of $\mathrm{ZnO}$ NPS which dark yellow color was appeared, this due to reduction of aqueous extracts by $\mathrm{Zn}$ $\mathrm{NO}_{3}$ (zinc ions) and formation of ZnO NPs. UVVis spectral analysis of reaction mixtures of $M$. nigra and $G$. robusta confirmed the synthesis of $\mathrm{ZnO}$ NPs from leaves aqueous extracts by the using of wave length scan at $296 \mathrm{~nm}$ (absorbance peak) and showed strong absorbance (Manokari

TABLE 2. Effect boiling period of aqueous extraction of Zn NPS.

\begin{tabular}{ccccccc}
\hline \multirow{2}{*}{$\begin{array}{c}\text { Plant } \\
\text { extracts }\end{array}$} & $\begin{array}{c}\text { Boiling } \\
\text { Period /min }\end{array}$ & $\mathbf{2 0 0}$ & $\mathbf{2 9 6 *}$ & $\mathbf{4 0 0}$ & $\mathbf{5 0 0}$ & $\begin{array}{c}\text { Absorbance (Optical Density, OD) } \\
\text { density }\end{array}$ \\
\cline { 3 - 7 } & 1 & 0.040 & $0.523 \mathrm{c}$ & 0.125 & 0.015 & ++ \\
M.nigra & 3 & 0.049 & $0.633 \mathrm{~b}$ & 0.134 & 0.022 & ++ \\
$(\mathrm{T} 5)$ & 6 & 0.100 & $0.753 \mathrm{a}$ & 0.145 & 0.061 & +++ \\
& 1 & 0.023 & $0.325 \mathrm{e}$ & 0.034 & 0.012 & + \\
M.nigra & 3 & 0.035 & $0.329 \mathrm{e}$ & 0.050 & 0.013 & + \\
$(\mathrm{T} 1)$ & 6 & 0.061 & $0.473 \mathrm{~d}$ & 0.071 & 0.017 & ++ \\
\hline
\end{tabular}

*296nm (absorbance peak) for Zinc NPs, Manokari et al. (2016). +: yellow ,++:dark yellow .+++: very dark yellow. 
et al. 2016). Green synthesis of metallic NPs using plant extracts was proved to popular and safe including water and nature extracts as safe solvents (Sivakumar et al. 2011; Russell et al. 1997). Synthesis of ZnO NPs by D. ericta and $M$. azedraech leaves extracts were reported by Ravindran et al. (2016) and Manokari et al. (2016), respectively and supporting the present results. Radzimska and Jesionowski (2014) found that, synthesis of metallic NPs from plant derivatives were reported and more attention due to vast application in the fields, due to their physic -chemical properties. Consequently, colloidal solution of $\mathrm{ZnO}$ NPs were used as nanofertilizer, absorbed rapidly, save fertilizer by slow release, minimizing pollution, had remarkable optical, physiological and antimicrobial properties therefore had great potential to enhance growth and yield (Lin and Xing 2007; Selivanov and Zorin 2001; Batsmanova et al.2013).

\section{3- Effect of nanoparticls of cercospora leaf spot disease}

Certain $\mathrm{Zn}, \mathrm{Mg}$ and $\mathrm{Ti}$ NPs were used to reduce and/or control of cercospora leaf spot disease under natural infection in the field in comparison of recommended fungicide Eminent and non sprayed control, results in Tables 3 and 4 showed that Ti NPS was the most effective one in reducing of cercospora DS in the two tested seasons especially concentration of $200 \mathrm{ppm}$ which recording 17.83 and $0.2 \%$ and efficiency against the disease i.e. 62.47 and $79.38 \%$ followed by 100 and $50 \mathrm{ppm}$ i.e. DS ranged from 27.0 to 0.46 and efficiency ranged from 42.10 to $52.58 \%$ in comparison of 2.50 and $0.1 \mathrm{DS}$ and 94.74 and 98.96\% efficiency of Eminent, whenever control recorded 47.51 and $0.97 \%$ DS in the two tested season, respectively. Zn NPs recorded positive effect against the disease i.e. DS recorded 37.53 $-0.46 \%$ and efficiency $21.01-52.58 \%$, while $\mathrm{Mg}$ NPS showed the lowest effect in this respect especially in season of 2015/2016 and DS recorded $50.0-0.47 \%$ and efficiency $0.00-51.54$ $\%$ in the two tested seasons. DS recorded very low percentages with all treatments and control in second seasons of study, so we will study effect of weather conditions of disease development later.

As to TSS and sucrose, TiNPs recorded the highest concentration especially in season of 2016/2017 with concentration $200 \mathrm{ppm}$ i.e. 23.10 and 18.48 followed by 100 and $50 \mathrm{ppm}$ i.e. 21.87 and $17.49 ; 21.73$ and 17.39 , respectively, as well

TABLE 3. Effect of nanoparticles spraying on cercospora leaf spot disease incidence, TSS and sucrose of sugar beet cv. oscarpoly, under field conditions in season 2015/2016

\begin{tabular}{|c|c|c|c|c|c|}
\hline \multirow{2}{*}{\multicolumn{2}{|c|}{$\begin{array}{l}\text { NPs- } \\
\text { Cons(ppm) }\end{array}$}} & \multicolumn{2}{|c|}{ Disease incidence \% } & \multirow{3}{*}{$\begin{array}{c}\text { TSS \% } \\
19.60 \mathrm{e}\end{array}$} & \multirow{3}{*}{$\begin{array}{c}\text { Sucrose \% } \\
15.68 \mathrm{~g}\end{array}$} \\
\hline & & \multirow{2}{*}{$\begin{array}{c}\text { Severity \% } \\
37.50 \mathrm{~cd}\end{array}$} & \multirow{2}{*}{$\begin{array}{c}\text { Efficiency\% } \\
21.05\end{array}$} & & \\
\hline $\mathrm{Zn}$ & 25 & & & & \\
\hline 50 & & $37.53 \mathrm{~cd}$ & 21.01 & $19.93 \mathrm{de}$ & $15.95 \mathrm{fg}$ \\
\hline 100 & & $32.50 \mathrm{de}$ & 31.59 & $20.47 \mathrm{c}$ & $16.37 \mathrm{~d}$ \\
\hline $\mathrm{Mg}$ & 25 & $42.51 \mathrm{abc}$ & 10.52 & $21.02 \mathrm{~b}$ & 16.80 be \\
\hline 50 & & $50.00 \mathrm{a}$ & - & $21.67 \mathrm{a}$ & $17.33 \mathrm{a}$ \\
\hline 100 & & $40.12 \mathrm{bcd}$ & 15.55 & $20.60 \mathrm{c}$ & $16.59 \mathrm{~cd}$ \\
\hline $\mathrm{Ti}$ & 50 & $27.51 \mathrm{e}$ & 42.10 & $21.60 \mathrm{a}$ & $17.28 \mathrm{a}$ \\
\hline 100 & & $25.00 \mathrm{ef}$ & 47.38 & $20.62 \mathrm{c}$ & $16.33 \mathrm{de}$ \\
\hline 200 & & $17.83 \mathrm{f}$ & 62.47 & $20.40 \mathrm{c}$ & $16.32 \mathrm{de}$ \\
\hline Emi & & $2.50 \mathrm{~g}$ & 94.74 & $21.33 \mathrm{ab}$ & $17.07 \mathrm{ab}$ \\
\hline Con & & $47.51 \mathrm{ab}$ & - & $19.73 \mathrm{de}$ & $15.79 \mathrm{fg}$ \\
\hline
\end{tabular}

In the same colum, means followed by a common letter are not significantly different at the $5 \%$ level by DMRT. 
TABLE 4. Effect of nanoparticles spraying on cercospora leaf spot disease incidence, TSS and sucrose of sugar beet cv. oscarpoly, under field conditions in season 2016/2017.

\begin{tabular}{|c|c|c|c|c|c|}
\hline \multirow{2}{*}{\multicolumn{2}{|c|}{$\begin{array}{l}\text { NPs- } \\
\text { Cons(ppm) }\end{array}$}} & \multicolumn{2}{|c|}{ Disease incidence, $\%$} & \multirow{2}{*}{ TSS (\%) } & \multirow{2}{*}{ Sucrose, $\%$} \\
\hline & & \multirow{2}{*}{$\begin{array}{c}\text { Severity \% } \\
0.47 \mathrm{c}\end{array}$} & \multirow{2}{*}{$\begin{array}{c}\text { Efficiency\% } \\
51.54\end{array}$} & & \\
\hline $\mathrm{Zn}$ & 25 & & & $21.33 \mathrm{e}$ & $17.07 \mathrm{c}$ \\
\hline 50 & & $0.50 \mathrm{c}$ & 48.45 & $21.57 \mathrm{bc}$ & $17.10 \mathrm{c}$ \\
\hline 100 & & $0.46 \mathrm{c}$ & 52.58 & $23.00 \mathrm{a}$ & $18.40 \mathrm{a}$ \\
\hline $\mathrm{Mg}$ & 25 & $0.47 \mathrm{c}$ & 51.54 & $20.93 \mathrm{~d}$ & $16.75 \mathrm{~d}$ \\
\hline 50 & & $0.63 \mathrm{~b}$ & 35.05 & $20.03 \mathrm{e}$ & $16.03 \mathrm{e}$ \\
\hline 100 & & $0.63 \mathrm{~b}$ & 35.05 & $20.13 \mathrm{e}$ & $16.11 \mathrm{e}$ \\
\hline $\mathrm{Ti}$ & 50 & $0.46 \mathrm{c}$ & 52.58 & $21.73 \mathrm{~b}$ & $17.39 \mathrm{~b}$ \\
\hline 100 & & $0.47 \mathrm{c}$ & 51.54 & $21.87 \mathrm{~b}$ & $17.49 \mathrm{~b}$ \\
\hline 200 & & $0.20 \mathrm{~d}$ & 79.38 & $23.10 \mathrm{a}$ & $18.48 \mathrm{a}$ \\
\hline \multicolumn{2}{|c|}{ Eminent } & $0.01 \mathrm{e}$ & 98.96 & $20.16 \mathrm{e}$ & $16.10 \mathrm{e}$ \\
\hline \multicolumn{2}{|c|}{ Control } & $0.97 \mathrm{a}$ & - & $20.00 \mathrm{e}$ & $16.01 \mathrm{e}$ \\
\hline
\end{tabular}

In the same colum, means followed by a common letter are not significantly different at the $5 \%$ level by DMRT.

as,100 ppm of Zn NPs showed enhancement of TSS and sucrose in the two seasons i.e. 23.0 and 18.40 in $2016 / 2017$ and $20.47 ; 16.37$ in 2015/2016, while $\mathrm{Mg}$ do that with $25 \mathrm{ppm}$ in the two seasons and $50 \mathrm{ppm}$ in the first season only. The other treatments showed no significant effect of TSS and sucrose with exception of Eminent in the first season in comparison of control but uncharacterized effect was done in the second season which low DS was recorded. Data concluded that, NPs of Ti and Zn with used cons can reduce of cercospora leaf spot disease severity and enhancement of TSS and sucrose under heavy DS (first season) in highly susceptible sugar beet cv. Oscarpoly in the field. This results were supported by the findings of Palmqvist et al. (2015), they found that $\mathrm{TiO}_{2} \mathrm{NPs}_{\text {s }}$ protected oilseed rape against $A$. brassicae infection and caused plant growth promoting of roots and increasing of adhesive force between $B$. amyloliquefaciens and plants by formation protective encapsulating interspecies (Chowdhury et al. 2012; Webster et al. 2008).

Moreover, Abd-Elsalam (2013) and Mahendra et al. (2012) added that NPs application needed to be readily used for protection against plant

Env. Biodiv. Soil Security Vol. 2 (2018) pathogens diseases. Also, NPs of Ti and Zn were promoted plant height, root length biomass yield and increase of chlorophyll, Raliya et al. (2015). In addition, TNPs lead to increase of nitrate reductase and enhance of absorbing water, stimulation the antioxidant effects and acceleration the germination and increased light absorption (Lu et al. 2002). Makhluf et al. (2005) and Stoimenov et al. (2002) mentioned that, NPs oxide of $\mathrm{Zn}, \mathrm{Ti}, \mathrm{Mg}$ are stable physically and optically; $\mathrm{Zn}$ and $\mathrm{Ti}$ (photocatalytic, increase light absorption), Baruah and Dutta (2009); Moreover, $\mathrm{TiO}_{2}$ have been improved crop yield through nitrogen photo-reduction with beneficial physiological responses and to incorporated into fertilizer as a photocatalytic bacteriocid, Larue et al. (2012). Schiling et al. (2010) added that, TNPs are considered to be save up to $30 \%$ in products of food. The results in the same line of Abd El-Hai et al. (2009) and Hamaza et al. (2013), they reported that, Zn NPs suppressed damping off, charchol rot diseases in sunflower and control of late wilt disease of maize and enhancement of yield, respectively. Moreover, Singh et al. (2013) added that, $\mathrm{NPs}_{\text {of }} \mathrm{CuSO}_{4}$ and $\mathrm{Na}_{2} \mathrm{~B}_{4} \mathrm{O}_{7}$ controlled rust disease of field peas, while $\mathrm{Zn}$ NPs spraying led to reducing of canker lesion and scab of grapefruit 
and melanose (Graham et al. 2016). Panwar et al. (2012) added that, $\mathrm{Zn}$ plays a vital role for plant diseases concerned to its deficiency and improved growth and yield. Farahat et al. (2017) found that, $\mathrm{Zn}$ and Ti NPS reduced ears and kernels rot disease and enhanced the maize yield, as well as, had strongly fungicidal effect against many pathogens i.e. A.niger and F. oxysprum (Lipovsky et al. 2011; Patra et al. 2012), A. flavus (Jayaseelan et al. 2012), Botrytis cinerea and Penicillium expansum (He et al. 2010; Krishnaraj et al. 2012), Helmenthosporium oryzae (Elamawi et al. 2016), F. verticillioids (Farahat et al. 2017) and bacterial proliferation (Dimkapa et al. 2011) due to induce intercellular generation of ROS, Roy Choudhurry et al. (2011). Muthurman et al. (2014) added that, application of ZnNPs mediated cytotoxicity, increase of lipid peroxidation, ROS and had been effective to control plant pathogens by generation of ROS, Wani and Shah (2012). Lin et al. (2009) added that, inhibitory mechanisms of ZnNPs into bacteria and fungi may induce continuous release of membrane lipid and proteins which changes the permeability. Hernandez et al. (2013) reported that, Zn NPs did not accumulate in the grains and thus were safe to use as a nutrient.

\section{4- Assay of peroxidase and polyphenoloxidase activities}

Since enzymes of peroxidase and polyphenoloxidase played an important and essential role in plant defense. So, activity of these enzymes were estimated with NPs which recorded a positive effect against $C$. beticola and enhancement of control to cercospora leaf spot disease in the field. Results in Table 5 showed that, spraying of sugar beet plants by nanoparticles led to activate of PO enzyme expressed as optical density after 3 min period estimation and recorded significant increase and high values with $200 \mathrm{ppm}$ of TiNPs and $100 \mathrm{ppm}$ of ZnNPs i.e. 1.463 and 1.326 (OD /3 $\mathrm{min} / \mathrm{gm}$ fresh weight), respectively, compared to 0.976 of control. On the other hand, $100 \mathrm{ppm}$ of MgNPs showed no significant deference with control treatment in this respect. Max. PO activity was recorded after 6 min, resulted in NPs application and the highest values of PO activity was recorded with TiNPs followed by $\mathrm{ZnNPs}$ while MgNPs recorded the lowest one i.e. 1.996, 1.801 and 1.691, respectively, compared to 1.651 of control treatment.

PPO enzyme activity continued up to $4 \mathrm{~min}$. and the used NPs led to significant increase of PPO activity in all estimation activity periods. PPO activity was gradually increase up to end of estimation periods. Highest values of PPO activity were recoded after 1 min estimation period with ZnNPs i.e. 1.323 and 1.501 (OD / min /gm fresh weight) after 4 min with MgNPs compared to 0.943 and 1.096 of control with the same two periods of estimation. Also, TiNPs caused significant increase of PPO activity and ranged from 1.153 to 1.456 in the fourth estimation periods. So, this NPs treatments induce sugar beet plants to produce defense enzymes of PO and PPO against cecospora leaf spot disease in the field conditions and cause reduction by this mechanism as well as, PO was more active than PPO recording positive activity up to 6 min estimation period. Many authors supported these results like Lin et al. (2009), who found that, ROS stress induced fungicidal mode of action of ZnNPs. Hamza et al.(2013) added that, ZnNPs can be promising to control of maize late wilt disease by increasing of PO enzyme activity. In addition to, Raghu et

TABLE 5. Effect of nanoparticles spraying of peroxidase and polyphenoloxidase enzymes activity of sugar beet $c v$. oscarpoly

\begin{tabular}{|c|c|c|c|c|c|c|c|}
\hline \multirow{2}{*}{\multicolumn{2}{|c|}{$\begin{array}{c}\text { Concentration of } \\
\text { nanoparticles (ppm) }\end{array}$}} & \multicolumn{2}{|c|}{$\mathrm{PO} / \mathrm{OD} / 3 \mathrm{~min} / \mathrm{g} \mathrm{FW}$} & \multicolumn{4}{|c|}{$\mathrm{PPO} / \mathrm{OD} / \mathrm{min} / \mathrm{g} \mathrm{FW}$} \\
\hline & & 3 & 6 & 1 & 2 & 3 & 4 \\
\hline $\mathrm{Zn}$ & 100 & $1.326 \mathrm{a}$ & $1.801 \mathrm{~b}$ & $1.323 \mathrm{a}$ & $1.343 \mathrm{~b}$ & $1.373 \mathrm{~b}$ & $1.363 \mathrm{c}$ \\
\hline $\mathrm{Mg}$ & 100 & $1.040 \mathrm{~b}$ & $1.691 \mathrm{c}$ & $1.253 \mathrm{~b}$ & $1.363 \mathrm{a}$ & $1.431 \mathrm{a}$ & $1.501 \mathrm{a}$ \\
\hline $\mathrm{Ti}$ & 200 & $1.463 \mathrm{a}$ & $1.996 \mathrm{a}$ & $1.153 \mathrm{c}$ & $1.293 \mathrm{c}$ & $1.366 \mathrm{c}$ & $1.456 \mathrm{~b}$ \\
\hline \multicolumn{2}{|c|}{ Control } & $0.976 \mathrm{~b}$ & $1.651 \mathrm{~d}$ & $0.943 \mathrm{~d}$ & $1.010 \mathrm{~d}$ & $1.056 \mathrm{~d}$ & $1.096 \mathrm{~d}$ \\
\hline
\end{tabular}

In the same colum, means followed by a common letter are not significantly different at the 5\% level by DMRT. 
al.(2014) and Anusuya and Sathyabama (2015) reported that, NPs of selenium and B-d glucan were significantly alteration of ROS(PO,PPO, glucanase and protease inhibitors) and protected turmeric plants against rot disease. Moreover, Lu et al. (2002) added that, TiNPs increase of nitrate reductase and stimulation antioxidant effects. Dimkapa et al. (2011), Lipovsky et al. (2011) and Patra et al. (2012), showed that, ZnNPs bactericidal and fungicidal due to induce ROS generation intracellular. Ti and $\mathrm{Zn}$ NPs exhibited strongly activator of PO enzyme and may play an essential role in reducing ears and kernels rot disease symptoms, restricting development of causal pathogens (Farahat et al. 2017). Although, increase of ROS effective to control plant pathogens (Wani and Shah, 2012). Lower disease severity in different plants was in line of high activity of protective enzymes of $\mathrm{PO}$ and $\mathrm{PPO}$ in rice (Datnoff et al. 2007), wheat (Nanayakkara et al. (2008) and cucumber (Rezende et al.2009). These enzymes regulation production of antifungal compounds like phenols, lignin and phytoalexins which assigned role in disease resistance (Vidhyasekaran 1988).

5-Effect of environmental conditions of cercospora leaf spot disease

a- Responsibility of sugar beet cultivars to cercospora leaf spot disease

Data in Table 6 recorded high disease severity percentages in 2015/2016 season than other one $2016 / 2017$, as well as, in the first date planting than the second one with most of tested sugar beet genotypes to cercospora leaf spot disease under field conditions. According to used scale of disease severity of Shane and Teng (1992),

TABLE 6. Response of nine sugar beet cultivars to cercospora leaf spot disease in seasons 2015/2016and 2016/2017 with two dates planting.

\begin{tabular}{|c|c|c|c|}
\hline \multirow[b]{2}{*}{ Genotypes } & \multirow[b]{2}{*}{ Seasons } & \multicolumn{2}{|c|}{ Disease severity \% } \\
\hline & & $\begin{array}{c}\text { First date } \\
\text { (September) }\end{array}$ & $\begin{array}{c}\text { Second date } \\
\text { (October) } \\
\end{array}$ \\
\hline \multirow{2}{*}{ Alouda } & $2015 / 2016$ & $30.00 \mathrm{de}$ & $31.66 \mathrm{c}$ \\
\hline & $2016 / 2017$ & $12.33 \mathrm{ghi}$ & $0.52 \mathrm{~g}$ \\
\hline \multirow{2}{*}{ Maimouna } & $2015 / 2016$ & $26.66 \mathrm{ef}$ & $17.33 \mathrm{e}$ \\
\hline & $2016 / 2017$ & $14.01 \mathrm{gh}$ & $1.01 \mathrm{~g}$ \\
\hline \multirow{2}{*}{ Beta 3980} & $2015 / 2016$ & $45.02 \mathrm{bc}$ & $36.66 \mathrm{bc}$ \\
\hline & $2016 / 2017$ & $14.33 \mathrm{~g}$ & $0.53 \mathrm{~g}$ \\
\hline \multirow{2}{*}{ Beta 8115} & $2015 / 2016$ & $48.33 \mathrm{~b}$ & $38.33 \mathrm{~b}$ \\
\hline & $2016 / 2017$ & $41.66 \mathrm{c}$ & $1.33 \mathrm{~g}$ \\
\hline \multirow{2}{*}{ Nefirtitis clg } & $2015 / 2016$ & $9.00 \mathrm{ghi}$ & $12.33 \mathrm{ef}$ \\
\hline & $2016 / 2017$ & $8.33 \mathrm{hi}$ & $0.41 \mathrm{~g}$ \\
\hline \multirow{2}{*}{ Cigogne } & $2015 / 2016$ & $7.33 \mathrm{i}$ & $8.33 \mathrm{f}$ \\
\hline & $2016 / 2017$ & 8.33 ghi & $0.17 \mathrm{~g}$ \\
\hline \multirow{2}{*}{ Toucan } & $2015 / 2016$ & $30.00 \mathrm{de}$ & $25.01 \mathrm{~d}$ \\
\hline & $2016 / 2017$ & $21.66 \mathrm{f}$ & $0.21 \mathrm{~g}$ \\
\hline \multirow{2}{*}{ Carnute } & $2015 / 2016$ & $31.66 \mathrm{de}$ & $38.33 \mathrm{~b}$ \\
\hline & $2016 / 2017$ & $31.67 \mathrm{de}$ & $0.93 \mathrm{~g}$ \\
\hline \multirow{2}{*}{ Oscarpoly } & $2015 / 2016$ & $55.00 \mathrm{a}$ & $45.08 \mathrm{a}$ \\
\hline & $2016 / 2017$ & $48.33 \mathrm{~b}$ & $2.01 \mathrm{~g}$ \\
\hline
\end{tabular}

In the same colum, means followed by a common letter are not significantly different at the $5 \%$ level by DMRT

Env. Biodiv. Soil Security Vol. 2 (2018) 
sugar beet genotypes of Alouda, Maimouna, Beta 3980 and 8115, Toucan, Carnute and Oscar poly expressed susceptible ones to the disease and recording disease severity ranged from 26.66 to $55.00 \%$ in season $2015 / 2016$ with first planting date (September), 17.33 to 45.08 with the second planting date (October) and 12.33to 48.33 and 0.21 to $2.01 \%$ in season $2016 / 2017$, respectively, while, Nefirtitis clg and Cigogne were resistant ones and recording disease severity ranged from 0.17 to 12.33 in the two tested seasons. The results showed significant differences in disease severity between two tested seasons with every tested susceptible genotype. Data showed also, dramatically decrease of disease severity in the second tested season $(2016 / 2017)$ with the two planting dates wherever recorded slight disease severity (very low infection). So, effect of weather conditions must be studied to explain this point.

b-Cercospora leaf spot disease development and metrological parameters effects

Aforementioned studies of both NPs and sugar beet genotypes were recorded high disease severity of cercospora leaf spot disease in season 2015/2016 than season 2016/2017 which recorded slight infection, that reflects the favorable weather conditions to cause and development of cercospora leaf spot disease. Data in Table 7 introduce the explanation of this results, whereas, max air temperature degrees recorded low values of periods of disease development in Feb. and March in second season of 2016/2017 ie 19.7and 21.7 compared to 22.58 and $24.5{ }^{\circ} \mathrm{C}$ of these months in the first season 2015/2016 so, max temperature degrees were more suitable for doing infection and disease development in the first season than the second one. Air min temperature degrees in Nov. and March recorded high values in second season 2016/2017 ie. 17.90 and 17.91 compared to 14.42 and 11.6 in same months in first season 2015/2016, also, cool weather in Jan. in the second season, this may be retarding the disease and/ or cause slight infection and decreasing disease severity in this season (2016/2017). RH\% at 13.30 PM recorded decreasing in months of Nov. and Dec. in season 2016/2017 (period of disease development of first date planting), as well as decrease of wind velocity in Nov., this led to decrease of disease severity in this date than the same one in season $2015 / 2016$. Whenever, wind help to distribution and transport of cercospora inoculum from field, location and date planting to others. Pan evaporation ( $\mathrm{mm}$ ) recorded very high amount in 2015/2016 season with all months and safe suitable conditions to spores germination, success of infection and disease development in the mentioned experiments above but the reverse was true in the season 2016/2017, so slight disease severity was showed in this season. Season of $2015 / 2016$ recorded high rain in the begging of disease development period (Nov.) and high total

TABLE 7. Grand mean of metrological parameters during the growing seasons 2015/2016 and 2016/2017 from November to March at Sakha Agriculture Research Station

\begin{tabular}{|c|c|c|c|c|c|c|c|c|}
\hline \multirow{3}{*}{ Seasons } & \multirow{3}{*}{ Month } & \multicolumn{4}{|c|}{ RH\% } & \multirow{3}{*}{$\begin{array}{c}\text { Wind } \\
\text { Km/24hrs }\end{array}$} & \multirow{3}{*}{$\begin{array}{c}\text { PE } \\
(\mathrm{mm})\end{array}$} & \multirow{3}{*}{$\begin{array}{l}\text { Rain } \\
(\mathrm{mm})\end{array}$} \\
\hline & & & & & & & & \\
\hline & & Max. & Min. & 7:30 AM & 13.30PM & & & \\
\hline \multirow{5}{*}{$\begin{array}{l}n \\
\stackrel{n}{0} \\
\frac{1}{0} \\
\stackrel{0}{0}\end{array}$} & Nov. & 24.4 & 14.42 & 87.0 & 64.2 & 70.3 & 813.5 & 16.14 \\
\hline & Dec. & 19.7 & 8.4 & 88.6 & 67.2 & 57.9 & 250.4 & 6.54 \\
\hline & Jan. & 18.4 & 6.5 & 85.6 & 62.5 & 69.2 & 252.4 & 5.10 \\
\hline & Feb. & 22.6 & 9.4 & 85.0 & 53.1 & 58.8 & 251.9 & 0.0 \\
\hline & Mar. & 24.5 & 11.6 & 81.5 & 58.3 & 63.2 & 359.2 & 4.2 \\
\hline \multirow{5}{*}{ 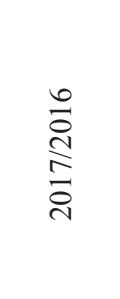 } & Nov. & 24.9 & 17.9 & 77.9 & 56.8 & 56.0 & 198.1 & 0.0 \\
\hline & Dec. & 19.3 & 10.8 & 85.4 & 65.1 & 64.7 & 156.4 & 7.1 \\
\hline & Jan. & 18.2 & 5.2 & 87.3 & 62.9 & 51.9 & 136.2 & 4.8 \\
\hline & Feb. & 19.7 & 10.2 & 85.8 & 60.1 & 58.3 & 214.4 & 4.8 \\
\hline & Mar. & 21.7 & 17.9 & 84.9 & 60.4 & 83.8 & 295.4 & 0.0 \\
\hline
\end{tabular}

Max. $=$ Maximum, Min. $=$ Minimum, $\mathrm{PE}=$ Pan evaporation, $\mathrm{RH} \%=$ Relative humidity 
rain amount i.e. 16.14 and $31.98 \mathrm{~mm}$ compared to 0.00 and $16.7 \mathrm{~mm}$ in season 2016/2017. High rain safe favorable RH to cause infection and disease development. So, grand mean of metrological factors were more suitable in season 2015/2016 than 2016/2017 for cercospora disease in sugar beet plants in Sakha location. Weather conditions were most effective elements of cercospora leaf spot disease infection and development and discussed by many researchers i.e. Kerr and Weiss (1990) found that, CLS was most destructive in warm humid conditions responsible for reducing of yield, sucrose and increasing of impurities and costs, Karaoglanidis et al. (2001). Windles et al. (1998) added that, C. beticola infection depending on weather conditions after infection. Consequently, Khan et al.(2007) reported that, unseasonably low temperature (15-16 compared to $22^{\circ} \mathrm{C}$ ) was the main factor for low disease severity, since bellow $10^{\circ} \mathrm{C}$ was strong inhibition for cercospora disease development, Shane and Teng (1984) but optimum ranged from $20-25^{\circ} \mathrm{C}$, disease was development between $20-30{ }^{\circ} \mathrm{C}$ and RH $75-90 \%$, free water, Wolf et al. (2001) and Wolf and Verreet (2005). Moreover, Khan et al. (2008) showed that, wind was the major dispersal factor for $C$. beticola inoculum and optimum temperature for spore germination 24.4 ${ }^{\circ} \mathrm{C}$ when RH was100\% (Jones and Windles 1991). Harveson (2013) concluded that, epidemics of CLS depending presence of susceptible varieties, adequate inoculum and RH above $90 \%$ longer 11 hours, accompanied by warm temperature in sugar beet canopy. Additionally, Salama (2017) reported that, adequate and suitable weather conditions for CLS disease were $16.66-26.9{ }^{\circ} \mathrm{C}$, $\mathrm{RH}$ (83.3695.86), wind velocity (35.0-91.88 km $/ 24 \mathrm{hr}$ and rain up to $16 \mathrm{ml}$ ). Ruppel (1986) added that CLS disease developed in favorable conditions $i e$. day temperature of 25 to $35^{\circ} \mathrm{C}$, night temperature of $16^{\circ} \mathrm{C}$, end prolong periods of $\mathrm{RH}$ of $90-95 \%$ or free water on leaves.

\section{Conclusion}

This study has further revealed that, M.nigra and G.robusta confirmed the bio synthesis of ZnONPs from leaves mix extracts (reaction mixture), certain nanoparticles treatments can reduce the cercospora leaf spot disease of sugar beet under field conditions and enhancement of TSS, sucrose and yield by activation of peroxidase and polyphenol oxidase enzymes, as well as, metrological parameters effects of cercospora leaf spot disease development were subjected.

Env. Biodiv. Soil Security Vol. 2 (2018)

\section{Acknowledgment}

We would like to express thanks and gratitude to all staff member in Plant Pathology Dept. and Horticulture Sakha Research Station especially Associate Prof. Rabab, M. A. Elamawi, Rice Research and Training Center, Sakha, Kafr ElSheikh 33717, Egypt for kind help, providing of nanoparticles, faithful effort and advising us during this research.

\section{References}

Abd El-Hai, K.M., El-Metwally, M.A., El-Baz, S.M and Zeid, A.M. (2010). The use of antioxidants and microelements for controlling damping off caused by Rhizoctonia solani and Macrophomonia phasoliana on sunflower. Plant Pathol.J. 8: 79-89.

Abd-Salam, K.A. (2013). Nanoplatforms for plant pathogenic fungi management. Fungal Genomics \& Biol.2(2): 107.

Aniruddha, B.P and Bhalchandra, M.B. (2013). Novel and green approach for the nano crystalline magnesium oxide synthesis and its catalytic performance in Claisen Schmidt Condensation. Catalysis Com. 36: 79.

Anjum, T., Fatima, S. and Amjad, S. (2012). Physiological changes in wheat during development of loose smut. Trop. Plant Patholo. 37(2): 102-107.

Anusuya, S. and Sathiyabama, M. (2015) Foliar application of B-d glucan nanoparticles to control rhizome rot disease of turmeric. Int. J. of Biological Macromolecules 72(1): 1205-1212.

Babu, S.A. and Prabu, G.H. (2011). Synthesis of AgNPs using the extract of Calotropis procora flower at room temperature. Mater.Lett. 65: 1675-1677.

Baruah, S. and Dutta, J. (2009). Nanotechnology application in pollution sensing and degradation in agriculture: A review. Environ. Chem. Lett. 7: 161-204.

Batsmanova, L.M., Gonchar, N.Y. and Taran Okanenko, A.A. (2013). Using a colloidal solution of metal nanoparticles as micronutrient fertilizer for cereals. Proc. of Int. Conf. Nano. 2(4): 2.

Bolton, M.D., Rivera, V. and Secor, G. (2013) Identification of the G143A mutation associated with Qol resistance in Cercospora beticola field isolates from Michigan, United States. Pest Manag. Sci. 69(1): 9-35.

Chowdhury, I., Cwiertny. D. M. and Walker, S.L. (2012). Combined factor influence the aggregation 
and deposition of nano - $\mathrm{TiO} 2$ in the presence of humic acid and bacteria. Environ. Sci. Technol. 46: 6968-6976.

Datnoff, L.E., Rodrigue, F.A. and Seebolt, K.W. (2007). Silicon and Plant Disease. Pages 233-246 in Mineral Nutrition and Plant Disease, L.E. Datnoff, W.H. Elmer and D.M. Huber, eds, American Phytopathological Society, St. Paul. MN.

Dimkapa, C.O., Calender, A., Britt, D.W., Mc Lean, J.E. and Anderson, A.J. (2011) Responses of a soil bacterium Pseudomonas chlororaphis O6 to commercial metal oxide nanoparticles compared with responses to metal ions. Eviron. Pollut. 159(7):1749-1756.

Elamawi, R. M., Bassiouni, S.M., Elkhoby, W. M. and Zayed, B.A. (2016). Effect of Zinc oxide nanoparticles on brown spot disease and rice productivity under saline soil. J. Plant Prot. and Path., Mansoura Univ., 7 (3): 171 - 181.

Farahat, G. A., Elamawi, R. M., Salama, N. H.H., Elmoghazy, S.M. and Hagag, E. S. (2017) Reducing of ears and kernels rot disease on maize by nanoparticles application. Egypt J. of Appl. Sci. 32(9): 48-75.

Graham, J.H., Johonson, E.G., Myers, M.E., Young, M., Rajasekaran, P., Das, S. and Santra, S. (2016). Potential of nano-formulated zinc oxide for control of citrus canker on grapefruit trees. Plant Disease 100(12): 2442-2447.

Hamza, A. M., El-Kot, G.A. and El-Moghazy, S.M. (2013). Non - traditional methods for controlling maize late wilt disease caused by Cephalosporium maydis. Egyptian J. of Biological Pest Control. 23(1): 87-93.

Harveson, R.M. (2013). Cercospora leaf spot of sugar beet. Neb. Guide Univ. Nebraska Ext. Inst.of Agric. and Nat.R.S.1998-2013.

He, L., Liu, Y., Mustapha, A. and Lin, M. (2010). Antifungal activity of zinc oxide nanoparticles against Botrytis cinerea and Penicillium expansum. Microbio. Res., doi : 10: 1016/j. micres.2010.03.003.

Hernandez-Viezcas, J.A., Castillo-Michel, H., Andrews, J.C, Cotte, M. Rico, C. et al. (2013). ACS Nano. 7: 1415-1423.

Jayaseelan, C., Rahman, A.A., Kirthi, A.V., Marimuthu, S. and Santhoshkumar, T. et al. (2012). Novel microbial route to synthesize $\mathrm{ZnO}$ nanoparticles using Aeromomans hydrophila and their activity against pathogenic bacteria and fungi
Spectrochimica Acta A: Mol. Biomol Spectosc. 90: 78-84.

Jones, R.K. and Windels, C.E. (1991). A management model for cercospora leaf spot of sugar beets.Univ. Minn.Ext.Cire AG-FO.5643-E.

Karaoglanidis, G.S., Thanassoulopouloss, C.C. and Loannidis, F.M. (2001).Fitness of Cercospora beticola field isolates resistant and sensitivity to demethylation inhibitor fungicides. Ear. J.Plant Pathol. 107: 337-342.

Khan, M.F.R. and Smith, L.J. (2005). Evaluation fungicides for controlling cercospora leaf spot of sugar beet. Crop Protection 244: 79-85.

Khan, M.R.and Rizvi, T.F. (2014). Nanotechnology: Scope and application in plant disease. Plant Patholo.J.13: 214-231.

Khan, M.R., Ashraf, S.,Rasool, F., Salati, K., Mohiddin, F.A. and Haque, Z (2014). Field performance of Trichoderma species against wilt disease complex of chickpea caused by Fusarium oxysporum f. sp.ciceri and Rhizoctonia solani Turk.J.Agric.Sci. 38: $447-454$

Khan, J, del Rio, L.E., Nelson, R. and Khan, M.F.R. (2007). Improving the cercospora leaf spot Management model for sugar beet in Minnesota and North Dakota. Plant Dis. 91: 1105-1108.

Khan, J, del Rio, L.E., Nelson, R., Rivera, V. and Secor, G.A. (2008).Survival dispersal and primary site for Cercospora beticola sugar beet. Plant Dis. 92: 741745.

Kerr, E.D. and Weiss, A. (1990). Fungicide efficacy and yield responses to fungicide treatment based on predication of cercospora leaf spot of sugar beet. J.Sugar Beet Res. 27: 58-71.

Kerr,E.D. and Weiss, A. (1998). Cercospora leaf spot of sugar beet. Hist.Mat.Univ.Neb-Lincolin Ext.Pap1255.

Krishnaraj, C., Ramachandran, R., Mohan, K. and Kalaichevan, P.T. (2012). Optimization for rapid synthesis of silver nanoparticles its effect on phytopathogenic fungi. Spectrochimica Acta A:Mol. Biomol Spectosc. 93: 95-99.

Kumar, V. and Yadav, S.K. (2009). Plant mediated synthesis of silver and gold nanoparticles and their applications. Chem. Technol. Biotechnol. 84: 151157.

Larue, C., Veronest, G., Flank, A.M., Surble, S., Herlin- 
Biome, N. and Carriere, M. (2012). J. Toxicol. Environ. Health, Part A,75: 722-734.

Lin, D. and Xing, B. (2007). Phytotoxicity of nanoparticles; inhibition of seed germination and root growth. Env.Poll. 150(2): 243-250.

Lin,Y.J., Xu, X.Y., Huang, L., Evans, D.G. and Li, D.Q.(2009). Bactericidal properties of $\mathrm{ZnO}-\mathrm{Al} 2 \mathrm{O} 3$ composites formed from layered double hydroxide precursors. J.Mater Sci. Med. 20: 591-595.

Lipovisky, A., Nitzan, Y., Gedanken, A., Lubart, R. (2011). Antifungal activity of $\mathrm{ZnO}$ nanoparticles, the role of ROS mediated cell injury. Nanotechnology 22: 105101

Liu, Y., He, L., Mustapha, A., Li, H. and Lin, M. (2010). Antibacterial activity of zinc oxide nanoparticles against Escherichia coli 0157:H7. J.App. Microbiol. 107(4):1193-1201.

Lu, C.M., Zhang, C.Y. Wen, J.Q.Wu.G.R. and Tao, M.X. (2002). Research of the effect of nanometer materials on germination and growth enhancement of Glycine max and its mechanism. Soybean Sc. 168-172.

Mahendra, R., Shivaji, R., Aniket, G. and Abd-Salam, K.A. (2012). Strategic nanoparticles - mediated gene transfer in plants and animals - a novel approach. Curr. Nanosci. 8: 170-179.

Makhluf, S., Dror, R., Natizan, Y., Abamovich, Y., Jelnek, R. and Gedanken, A. (2005). A microwave -assisted synthesis of nanocrystaline $\mathrm{MgO}$ and its use as a bacteriocide. Adv. Funct.Mater 15: 17081715.

Manokari, M., Ravindran, C.P. and Shekhawat, M.S. (2016). Biosynthesis of zinc oxide nanoparticles using Melia azedarach L. extracts and their characterization. Int. J. of Pharm. Sci. and Res. 1(1): 31-36.

Matta, A. and Dimond, A.E. (1963). Symptoms of fusarium wilt in relation to quantity of fungus and enzyme activity in tomato stems. Phytopathology, 53: $574-575$.

McGinnis, R.A. (1982). Beet Sugar Technology. 3 rd Ed. Beet Sugar Development Foundation. Fort Collins 855 p.

Muthurman, P., Ramkumar, K. and Kim, D.H. (2014). Analysis of dose - dependent effect of zinc oxide nanoparticles on the oxidation stress and antioxidant enzyme activity in adipocytes. App. Biochem. and Biotech. 9: 12010-12014.

Env. Biodiv. Soil Security Vol. 2 (2018)
Nanayakkara, U.N., Uddin, W. and Datnoff, L.E. (2008). Application of silicon sources increases silicon accumulation in perennial ryegrass turf on two soil types. Plant Soil 303: 83-94.

Palmqvist, N.G.M., Bejai,S., Seisenbaeva, G.A. and Kessler, V.G. (2015). Nano titania aided clustering adhesion of beneficial bacteria to plant roots to enhance crop growth and stress management. Scientific rep5.no.10146.doi.10:.1038/srep10146.

Panwar, J., Jain, N. Bhargaya, A., Akthtar, M.S. and Yun, Y.S. (2012). Positive effect of zinc oxide nanoparticles on tomato plants : A step towards developing nano - fertilizers. $3 \mathrm{rd}$ Int. Con. on Environ. RES. and Technol. (ICERT). 30 May-1 June 2012, Parkroyal, Malaysia.

Patra, P., Mitra, S., Debnath, N. and Goswami, A. (2012). Biochemical, biophysical and microarray -based antifungal evaluation of the buffer mediated synthesized nano Zinc Oxide :an in vivo and in vitro toxicity study. Langmuir 28: 16966-16978.

Radzimska, A.K. and Jesionowski, T. (2014). Zinc oxide from synthesis to application: A review. Materials 7: 2833-2881.

Raghu, K.G., Soumya, R.S., Vineetha, V.P. and Salin Raj, P. (2014). Beneficial properties of selenium incorporated guar gum nanoparticle against ischemia reperfusion in cardiomyoblast $(\mathrm{HgC} 2)$. Metallomics 10: 1039/C4MToo241E.

Raliya, R., Nair. R., Chavalmane, S., Wang, W.N. and Biswas, P. (2015). Mechanistic evaluation of translocation and physiological impact of titanium dioxide and zinc oxide nanoparticles on the tomato (Solanum lycopersicum L.) plants. Metallomics 7: 1584-1594.

Ravindran, C.P., Manokari, M. and Shekhawat M, S. (2016). Biogenic production of zinc oxide nanoparticles from aqueous extracts of Duranta erecta L. World Sci. News. 28: 30-40.

Rezende, D.C., Rodrigues, F.A., Crre-Missio, V., Schuri, D.A., Kawamura, I.K. and Korndorfer, G.H. (2009). Effect of root and foliar application of silicon on brown spot development in rice. Aust. Plant Pathol. 38: 67-73.

Roy Choudhury, S., Ghosh, M., Mandal, A., Chakravotry, D., Paul, M., Pradhan, S. and Goswami, A. (2011). Surface - mediated sulfur nanoparticles: An effective antifungal agent Aspergillus niger and Fusarium oxysporum. Appl. Microbiol. Biotechnol. 90: 733-743. 
Ruffollo, S.A., La Russa, M.F., Malagodi, M., Oliviero Rossi, C., Palmer, A.M. et al. (2010). $\mathrm{ZnO}$ and $\mathrm{ZnO}$ $\mathrm{TiO} 3$ nanopowders for antimicrobial stone coating. App. Phys. A 100: 829-834.

Ruppel, E.G.(1986). Cercospora leaf spot. Pages 8-9 in Compendium of Beet Diseases and Insects E.D. Whitney and J.E. Duffus, ed. American Phytopath. Society, St.Paul, MN.

Russell, A.B., Hardin, J.W. and Grand, L. (1997). Melia azedarach. Int. Poisonous Plants of North Carolina.

Salama, N.H.H (2017). Survival of cercospora fungus inoculum in different soils and depths \&forecasting of cercospora leaf spot disease under field conditions. Egypt J.Plant Proc. Res.5(1): 73-90.

Salem, W., Leitner, D.R., Zinble, F.G. Schratter, G., Prassi, R., Goessler, W., Reidl, J. and Schild, S. (2015). Antibacterial activity of silver and zinc nanoparticles against Vibrio cholera and entertoxic Echerichia coli. In. J.of Med. And Microb. 305: 8595.

Sangeetha, G., Rajeshwan, S. and Venckatesh, R. (2011). Green synthesis of zinc oxide nanoparticles by aloe bathadensis miller leaf extract. Structure and optical properties. Mater.Res.Bull. 46: 25602566.

Schiling, K., Bradford, B., Castelli, D., Dufour, E., Nash, J.F., Pape, W., Schulte, S., Tooley, I., Bosch, J. and Schellauf, F. (2010). Human safety review of nano titanium dioxide and zinc oxide. Photochem. Photobiol. Sci. 9: 495-509.

Secor, G.A. and Rivera, V.V. (2010). Monitoring fungicide sensitivity of Cercospora beticola of sugar beet for disease management decision. Pant Disease 94: 1272-1282.

Selivanov, V.N. and Zorin, E.V. (2001). Sustained action of ultrafine metal powder on seed of grain crops. Prespect Materialy 4: 66-69.

Shane, W.W. and Teng, P.S. (1984). Cercospora beticola infection prediction model: 1983. Sugar Beet Res. Ext.Rep.N.D.State Univ. Fargo 14:174-179.

Shane, W.W. and Teng, P.S. (1992). Impact of Cercospora leaf spot on root weight, sugar yield and purity of Beta vulgaris. Plant Dis. Rep. 76(8): 812-820.

Singh, D., Kumar, A., Singh, A.K. and Tripathi, H.S. (2013). Induction of resistance in the field pea against rust disease through various chemicals/ micronutrients and their impact on growth and yield. Plant Pathol.J. 12: 36-49.

Sivakumar, J., Premkumar, C., Santhanan, P. and Saraswathi, N. (2011). Biosynthesis of silver nanoparticles using Calotropis gigantean leaf. African J. of Basic App. Sci. 3(6): 265-270.

Song, S., You, B., Zhu,Y., Ling, Y.,Wu, Y. and Gel, X. (2014). Nanocrystal-organic hybrid antifungal agent: High level oriented assembly of Zinc hydroxide carbonate nanocrystals in chitosan. Cryst. Growth Des. 14(1): 38-45.

Stewart, J. (2011). The News Beet. 25(1): 14 p.

Stoimenov, P.K.; Klingers, R.I.; Marchin, G.L. and Kalunde, K.J. (2002). Metal oxide nanopartticles as bactericidal agents. Langmuir 18: 6679-6686.

Suzan, A., Mansor, B.A., Faredeh, N. and Rosfarizan, M. (2014). Green biosynthesis and characterization of zinc oxide nanoparticles using brown marine microalga Sargassum muticum aqueous extract. Mater. Lett. 275-277.

Vidhyasekaran, P. (1988). Physiology of Disease Resistance in Plants, Vol. 11, C RC, Press Florida. p. 128

Wani, A.H. and Shah, M.A. (2012). A unique and profound effect of $\mathrm{MgO}$ and $\mathrm{ZnO}$ nanoparticles on some plant pathogenic fungi. J. of Appli. Pharama. Sci. 2: 40-44.

Webster, T.J., Park, M.R., Banks, M.K. and Applegate, B. (2008). Influence of nanophase titiania topography on bacteria attachment and metabolism Int. J. Nanomed. 3: 497-504.

Windels, C.E., Arthur, H. L., Hilde, D., Widner J. and Knudsen,T. (1998). A cercospora leaf spot model for sugar beet: Impractical by an industry. Plant Dis. 82: 716-726.

Wolf, P.F.J. and Verreet, J.A. (2005). Factors affecting the onset of cercospora leaf spot epidemics in sugar beet and establishment of disease monitoring threshalds. Phytopath.95:269-274.

Wolf, P.F.J., Hendl, M. and Verreet, J.A. (2001). Zumeinflub des bestani dsklimas auf die pradis position du zuckerrube gegenub infection en vor Cercospora beticola (Sacc). Z.Pflanzenkrankh. Pflanzenschulz. 108: 578-592.

(Received 20/9/2018; accepted 15/12/2018)

Env. Biodiv. Soil Security Vol. 2 (2018) 